VOLUME 21 - ISSUE 1 -MARCH 2021

JOURNAL OF

\title{
EAST ASIAN
}

STUDIES 
Editor

Stephan Haggard, University of California, San Diego

\section{Managing Editor}

Yewon Hong, East Asia Institute

\section{Book Review Editor}

Yves Tiberghien, University of British Columbia

The Journal of East Asian Studies is devoted to publishing cutting edge social science on East and Southeast Asia. The journal is interested in work that combines theory, novel empirical contributions, and engagement with the major substantive issues facing the region. The JEAS publishes primarily in the fields of international relations, including both international political economy and security studies, and comparative politics. However, we welcome interdisciplinary work and contributions from sociology, applied economics, and business studies as well. The journal is also open to roundtables on important new books on the region, review essays and shorter research notes. SSCI indexed, the journal prides itself on a strong peer-review process.

\section{Subscription information}

The Journal of East Asian Studies is published three times a year (March, July, and November) by Cambridge University Press, One Liberty Plaza, New York, NY 10006, USA.

The subscription price of Volume 21 (2021) including delivery by air where appropriate (but excluding VAT), is \$252 ( $£ 152$ ) for institutions print and online, \$227 (£136) for institutions online only. Individual subscriptions are available at $\$ 82$ (£51) for print and online and \$74 (£45) for online only.

Orders, which must be accompanied by payment, may be sent to a bookseller, subscription agent or direct to the publisher: Cambridge University Press, Journals Fulfillment Department, One Liberty Plaza, New York, NY, 10006, USA; or Cambridge University Press, UPH, Shaftesbury Road, Cambridge CB2 8RU, England. Alternatively, orders may be placed online at cambridge.org/jea.

For single issues, please contact subscriptions_ newyork@cambridge.org.

\section{Advertising}

For information on display ad sizes, rates, and deadlines for copy, please visit the journal homepage at cambridge.org/jea or contact USAdSales@ cambridge.org.
ISSN: $1598-2408$

EISSN: 2234-6643

(C) East Asia Institute, 2021. All rights reserved.

No part of this publication may be reproduced, in any form or by any means, electronic, photocopying, or otherwise, without permission in writing from Cambridge University Press. Policies, request forms and contacts are available at: http://journals. cambridge.org/action/rightsAndPermissions

Permission to copy (for users in the U.S.A.) is available from Copyright Clearance Center http:// www.copyright.com, email: info@copyright.com.

Postmaster: Send address changes to Journal of East Asian Studies, Cambridge University Press, One Liberty Plaza, New York, NY 10006, USA. 


\title{
Journal of East Asian Studies
}

\author{
Volume $21 \quad$ Number $1 \quad$ March 2021
}

\section{Articles}

Why Divide Migrants by their Types?: Contacts and Perceptions of Migrants in Japan $₫$ Yujin Woo

Leviathan for Sale: Maritime Police Privatization, Bureaucratic Corruption, and the Sewol Disaster $=$ Kyong Jun Choi and Jonson N. Porteux

Embedded and Autonomous Markets in North Korea's Fishing Industry: Resource Scarcity, Monitoring Costs, and Evolving Institutions $₫$ Peter Ward, Andrei Lankov and Jiyoung Kim

Is Trading with China Different? Self-interest, National Pride, and Trade Preferences = Wei-Ting Yen, Kristine Kay and Fang-Yu Chen

Opposition Repertoires under Authoritarian Rule: Vietnam's 2016 Self-Nomination Movement $₫$ Nhu Truong

Ethnic and Religious Sentiments in Indonesian Politics: Evidence from the 2017 Jakarta Gubernatorial Election $\approx$ Nathanael Gratias Sumaktoyo

\section{Book Reviews}

Kishore Mahbubani. Has China Won?: The Chinese Challenge to American Primacy

Reviewed by Hailey Clarke

Daniel A. Bell. The China Model: Political Meritocracy and the Limits of Democracy

Reviewed by Charlotte Hook

Frank M. Snowden. Epidemics and Society: From the Black Death to the Present

Reviewed by Marna L. Swart

Benoît Vermander, Liz Hingley and Liang Zhang. Shanghai Sacred: The Religious

Landscape of a Global City

Reviewed by Jonathan Brasnett 